\title{
"KAD SI OPUŠTEN, TADA MOŽEŠ DATI SVE OD SEBE": ETNOGRAFIJA RADA U PULSKOJ ARENA TRIKOTAŽI
}

Izvorni znanstveni članak Primljeno: 19. 1. 2018. Prihvaćeno: 22. 2. 2018 DOI: $10.15176 /$ vol55no106 UDK 39:331(497.5 Pula)"1947/2014"

\section{MAJA MAKSIĆ}

Nezavisna istraživačica, Pula

\section{ANDREA MATOŠEVIĆ}

Fakultet za interdisciplinarne, talijanske i kulturološke studije

Centar za kulturološka i povijesna istraživanja socijalizma

Sveučilišta Jurja Dobrile u Puli

\begin{abstract}
U radu se zahvaća u dio bogate, ali i podistražene radne prošlosti trikotaže Olga Ban, odnosno Arena modne trikotaže koja je u gradu Puli osnovana 1947., a zbog stečaja zatvorena 2014. godine. Kroz osam intervjua s nekadašnjim radnicama i radnicima u radu se otvaraju i analiziraju teme koje su, iz razgovora proizlazi, radnicima bile od većeg značaja: uvjeti rada, plaće, organizacija rada, double burden, odnosi među radnicima i predradnicima, ali i sjećanje na neposredno poraće i sudjelovanje na radnim akcijama izvan zidina tvornice kao i na opadanje kvalitete uvjeta rada i proizvoda - proces koji je simultan s prelaskom u postsocijalistički period. Dok je period socijalizma osvjedočen kao težak za ženski rad, ali pritom bolje organiziran i egzistencijalno sigurniji, tvornički je menadžment u periodu postsocijalizma okarakteriziran kao previše opušten i manje organiziran u usporedbi s prethodnim periodom organizacije rada i poslovanja. Zatvaranje Arena trikotaže značilo je rastakanje dijela lokalne zajednice unutar koje su žene mogle steći financijsku neovisnost i šire priznanje za vlastiti rad.
\end{abstract}

Ključne riječi: Arena trikotaža, Pula, industrija, radni odnosi, uvjeti rada

Pula, najveći grad u Istri, u drugoj polovici 20. stoljeća isticao se rastućim tercijarnim sektorom i prepoznavao po "snažnim" kulturnim manifestacijama dominantno obilježenima Festivalom jugoslavenskog igranog filma. No, važna sastavnica pulskoga identiteta bio je i industrijski sektor, koji se svojim posebnostima upisao i u sliku kulture grada. Među industrijskim postrojenjima najveći je i najvažniji dakako bio Scoglio Ulivi - Uljanik, brodogradilište koje je nerijetko bilo generator razvoja samoga grada, ${ }^{1}$ ali u njemu su, uz rijetke

\footnotetext{
${ }^{1}$ Uljanik je osnovan 1856. kao K.u.K. See-Arsenal na otočiću imena Olivieninsel, Scoglio Olivi ili Uljanik. Razvoj Pule usko je vezan uz brodogradilište jer je ono bilo izvor demografskog, infrastrukturnog, sportskog i
} 
izuzetke žena i djevojaka, posao nalazili gotovo isključivo muškarci. ${ }^{2} U$ izokretanju trenda poistovjećivanja industrije i maskuliniteta u FNRJ i SFRJ ogromnu ulogu odigrala je upravo "laka industrija", poglavito tvornice za proizvodnju trikotažnih odjevnih predmeta. lako su žene $u$ Istri i prethodno bile zaposlene u duhanskoj industriji, poput rovinjskih "tabacheina kojima je zapošljavanjem rastao društveni status i osjećaj superiornosti u odnosu na radnice u tvornicama za preradu ribe" (Nikolić-Đerić 2011: 281), u gradu Puli krajem 1947. godine, u prostoru bivše talijanske tvornice duhana, otvoreno je postrojenje za proizvodnju trikotažnih odjevnih predmeta. Bio je to važan trenutak za stanovnike grada: u vrlo kratkom periodu broj radnika, većinom žena, popeo se na 150. U periodu prije Drugog svjetskog rata nije bilo tradicije "šire organizirane tkalačke proizvodnje" takvog tipa te u počecima rada tvornice zaposlene radnice nisu bile kvalificirane trikotažerke, no sukladno dominantnoj politici rada stručno su se kvalificirale i obučile kroz škole koje su pohađale nakon radnog vremena. Od svog osnivanja 1947. godine postrojenje naknadno nazvano Arena modna kuća 3 predstavlja značajan gospodarski subjekt grada Pule, ali i SR Hrvatske kao i Jugoslavije: već na početku godišnje se izrađivalo oko 190.000 komada raznih proizvoda (Stojšić 1982: 183). Time je otvoren put k ženskoj ekonomskoj emancipaciji te stvoren snažan kontrapunkt ideji muškarca kao isključivog proizvođača i kruhonosca. ${ }^{4}$ No, put do tog cilja nije bio nimalo lagan, a mikrodinamike odnosa u postrojenjima, utkane u put egzistencijalnog boljitka, vrlo su često ostajale u domeni "nezapisanog" znanja samih trikotažerki pa se metoda etnografskog istraživanja, razgovora s dvanaest nekadašnjih

kulturnog zamašnjaka u gradu. Još 2003. godine brodogradilište je imalo 2000 zaposlenih uz još oko 1000 kooperanata (Markulinčić 2005: 836). Zbog problema u poslovanju od 2017. godine, prema informacijama koje se mogu čuti od radnika zaposlenih u brodogradilištu, taj je broj zaposlenih u stalnom opadanju te se čeka restrukturiranje poslovanja Uljanika. Te će se promjene odnositi ne samo na broj zaposlenih već i na sužavanje prostora na kojem se brodogradilište nalazi te diversifikaciju proizvodnje.

2 Jedna od nekoliko žena zaposlenih u Uljaniku je Fatima Zahirović - zavarivačica. lako je njezina "kći ponosna na nju", Fatimi je "ponekad neugodno reći čime se bavi" (Glas Istre, 13. travnja 2013.).

${ }^{3}$ Godine 1950. trikotažu na upravljanje preuzimaju radnice, čiji broj već tada doseže 314 . Dvije godine nakon toga tvornica dobiva ime po ubijenoj mladoj partizanki Olgi Ban. Poduzeće Olga Ban nije moglo pratiti svjetske trendove u proizvodnji, zbog zastarjelosti strojeva i manjka stručnog kadra. Problem se nastojao riješiti 1962. godine integracijom s drugim dvjema istarskim tvornicama trikotaže, Umber Gorjanom iz Novigrada i Istrankom iz Pazina, u poduzeće pod nazivom Arena. Poboljšanje stanja u tvornicama, kako je bilo zamišljeno, nije se pokazalo uspješnim te stoga 1968. godine dolazi do razdvajanja, tj. do istupanja tvrtke iz Novigrada. Od tada trikotaže iz Pule i Pazina nastavljaju suradnju pod imenom Arena - trikotažna industrija. Godine 1979. Arena opet doživljava promjene u organizaciji zbog potrebe usklađivanja s odredbama Zakona o udruženom radu te postaje jedinstvena radna organizacija u čijem sastavu djeluju dvije osnovne organizacije: Tvornica trikotaže Olga Ban i Tvornica trikotaže Istranka u Pazinu. Arena je za svoje kreacije dobila niz priznanja, od kojih je najznačajnija plaketa "Kate Pejnović” (Stojšić 1982: 184-187). Nakon što radnicima od lipnja 2013. do siječnja 2014. godine plaće nisu isplaćene zbog čega radnice i radnici ulaze u tromjesečni štrajk, tvornica je nakon stečajnog postupka sredinom 2014. godine zatvorena čime su posljednja 62 zaposlenika ostala bez posla. Tijekom 2017. godine u napuštenim se prostorijama otvorio Museum Olei Histriae - Kuća istarskog maslinovog ulja.

${ }^{4} \mathrm{U}$ tom je smislu zanimljiva i prostorna distribucija između postrojenja u kojima dominantno vlada muški, odnosno ženski rad jer su Uljanik i Arena trikotaža smješteni na pulskoj rivi, jedan nasuprot drugoga. Također, pored već spomenutih rovinjskih tabacheina i radnica u tvornici za preradu ribe, istarski je industrijski sektor snažno obilježen i labinskim i raškim ugljenokopima koji su također, vjerojatno i više nego brodogradilište, gotovo isključivo domena muškog zapošljavanja. Za slovenski primjer usporedbe Litija i Trbovlja, odnosno lake i teške industrije vidi Vodopivec (2011). 
radnica, ${ }^{5}$ ispostavila vrlo plodonosnom u, barem djelomičnom, otkrivanju njihove radne svakodnevnice. Upravo će dio njihove radne svakodnevnice biti okosnica ovoga rada kojim smo također, grosso modo, pokušali dijakronijski i pojedinim odabranim temama zahvatiti cjelokupan životni vijek od šezdeset i sedam godina danas ugašene tvornice. Teme kojima smo posvetili veću pažnju u ovome radu stoga proizlaze iz iskaza, to su teme koje su sugovornice tijekom intervjua posebno naglašavale kao njima bitne. Time smo se pridružili pozivu istraživača u domeni rodne memorije rada poput Marie Tamboukou da pažnju "posvetimo polemičkim pričama krojačica kao tragovima njihove memorije na rad i borbu [...]. Kao što relevantna literatura pokazuje, pojedinosti i zaboravljeni detalji svijeta rada dozvoljavaju pogled u prošlost; takvi 'trenutci postojanja' u kulturi rada mogu biti predivno uhvaćeni kroz radničke usmene ili pismene narative" (Tamboukou 2016: 2). Pošto se kod Tvornice Olga Ban, odnosno Arena trikotaže, radi o vremenskom periodu koji zahvaća rad pod socijalističkim društvenim uređenjem kao i rad u periodu postsocijalizma s njihovim specifičnostima i ambivalencijama na koje su već primjerima Tvornice Jugoplastika i Tvornice i predionice konca Dalmatinka u Sinju uputile Renata Jambrešić Kirin i Marina Blagaić (2013), odnosno Jelena Pavlinušić i dr. (2017), u našem smo radu nešto više pažnje posvetili iskustvima prvih godina, odnosno početku rada tvornice kao i onima u periodu koji je prethodio definitivnom zatvaranju postrojenja 2014. godine. Ta su dva očišta, vremenske odrednice početka i kraja, u memoriji sugovornika djelovale kao one koje sa sobom nose posebno snažan egzistencijalni i simbolički otisak.

\section{IZMEĐU ZARADE I RADA}

Jedna od najprimjetnijih razlika koja se ocrtala tijekom istraživanja ona je između sugovornica starijeg naraštaja i radnica koje su svoje radno iskustvo okončale odlaskom Trikotaže u stečaj 2014. godine. Te su razlike uočljive u svim segmentima njihovog odnosa prema radu, motivaciji, ali i životu izvan tvornice. Žene ranije generacije pripovijedaju o svom entuzijazmu u vrijeme izgradnje jugoslavenskog socijalizma, dok druge, mlađe trikotažerke, svjedoče o krizi socijalističke ekonomije i razdoblju koje će slijediti - procesu pretvorbe i privatizacije 1990-ih te gašenju proizvodnje na valu šireg regionalnog procesa deindustrijalizacije (usp. Vodopivec 2011: 228-229). ${ }^{6}$

Žene su se u poraću uglavnom zapošljavale bez kvalifikacija. Po dolasku u tvornicu mijenjale su radna mjesta sve dok se ne bi pronašlo ono koje im je najbolje odgovaralo, na kojem su bile najbrže, najpreciznije, a time i najproduktivnije. Jedna od sugovornica prisjetila se svog školovanja za konfekcionerku:

\footnotetext{
${ }^{5}$ Za potrebe ovoga rada koristili smo dijelove intervjua s osam sugovornica.

${ }^{6}$ Za period tranzicije koji koincidira i s periodom deindustrijalizacije na primjeru Jugoslavenskog kombinata gume i obuće Borovo vidi Cvek, Ivčić i Račić (2015); za gubitak srednjeklasnog habitusa s propašću industrije na primjeru sisačke željezare vidi Škokić i Potkonjak (2016).
} 
Ajme meni, kad san išla u školu san patila ko tovar. Ujutro delati, popodne u školu, pa meni se spavalo, oči su mi se zatvarale. Su mi se smijali, ja sam padala i tako. Da, navečer u školu za napraviti kvalifikaciju za konfenkcionerku. (M. H., intervju)

Odustajanje, kažu, nije bila opcija. Posebno u periodu obnove i izgradnje kasnih četrdesetih godina jer uzlazna putanja obnove i razvoja države stvorila je atmosferu zajedništva i radnici su dobrobit kolektiva, nerijetko, stavljali ispred svoje osobne. Napose u poraću, društvena je klima bila nošena i politikom rada Pokreta za visoku produktivnost, u kojem su radnice u trikotažama imale nemalu i medijski gdjekad vrlo istaknutu ulogu (Matošević 2015a: 83-90).? Pregalački rad, značajno je, nije bio rezerviran samo za postrojenja tvornice već se ponekad, a napose tijekom poraća, obavljao i izvan mjesta zaposlenja. Sugovornice starije generacije mahom su se prisjećale sudjelovanja u radnim akcijama, a u kojima su, pored šireg pučanstva, sudjelovali i najuspješniji radnici iz tvornica. Jer, nakon rata grad i širu okolicu trebalo je obnoviti, ali i izgraditi i modernizirati. Među mnogima tu čast dobile su i najbolje radnice Trikotaže te su pozivane na radne akcije i izvan granica grada. ${ }^{8}$ Tako su radnice 1950. godine u mjesecu listopadu otišle na tromjesečnu izgradnju pruge Lupoglav-Štalije. ${ }^{9}$ lako smještene u zasebnim zgradama, žene su radile iste poslove na pruzi kao i njihovi muški kolege:

Navečer smo delali do škurega, pokle si ima za isti, i bila je velika prostorija, forši pedeset nas, saka je spala šoto jedne (na kat). To su bile kao vojne, tu na sredini je bila naštuvana drva i tu ča smo si oprale robu se osušila, ali ti nisi smrdia ni niš jer nije bilo sintetika kao sada. Svako toliko bimo jedna drugoj život oprle. [...] I tamo nam je bilo lipo pa su došle nike Dalmatinke. Nepismene su bile. Pa znaš, mi smo im pisali doma pisma. Svi bismo se smijali. Pa navečer pričali priče. A imali smo komandanta jako strog. A vraga znaš je bilo i mladih i muških i ženskih pa smo se gledali. [...] Tako da smo mi bile u Rašu na mostu ujutro lipo bimo uzele šugaman ča si ima, poša na potok lipo se oprati. (A. Š., intervju)

7 Primjerice, među eksponiranijim pojedincima Pokreta za visoku produktivnost, udarničkog pokreta kojim se tijekom poraća pokušala podići proizvodnost u svim sektorima teške i lake industrije, bile su i Slavica Travnikar, tekstilna radnica tvornice Ivančica koja je radila na dvadeset automatskih tkalačkih strojeva, Barica Šćulac i Sonja Erbežnik, jedanaesterostruka udarnica i buduća predsjednica radničkog savjeta tvornice Nada Dimić, koja je u trećoj planskoj godini, dakle 1950., izvršila petogodišnji plan. Erbežnik je svoj dio plana izvršila za dvije godine, osam mjeseci i dvadeset jedan dan; u tom je vremenu izradila 74,780 komada trenerki i preuzela novu obvezu, da će svoj drugi petogodišnji plan izvršiti do kraja godine 1951. (Glas Istre, lipanj 1949.). O svom udarničkom zalaganju pripovijedala nam je jedna od naših sugovornica: "Prvi put već kad se fabrika organizirala, onda sam bila jer ki je najviše normu postiga je bia udarnik, pa san bila i udarnik ne znam ni sama kolike pute. Kao najbolja radnica. Onda to je pisalo na ploči u portirnici. Kapiš? Na oglasnoj ploči. To je jako ponos bio" (A. Š., intervju).

${ }^{8}$ Omladinske radne akcije ili samo radne akcije u FNRJ i SFRJ imale su nekoliko faza i predstavljaju važan aspekt izgradnje infrastrukture, ali i društva. Prva je faza obilježena većim stavljanjem naglaska na rad i završava 1952., dok je druga faza, započeta 1958. ponovnim otvaranjem trase na Autoputu Bratstvo-jedinstvo posebno podcrtavala ulogu razvoja kulture i samoupravljanja na jednomjesečnim boravcima izvan vlastitog mjesta prebivališta. U kasnijim fazama u ORA sudjeluju pretežno studenti i srednjoškolci, dok na onim prve faze sudjeluju svi koji su mogli, odnosno htjeli doprinijeti obnovi i izgradnji (usp. Senjković 2016: 281-316).

${ }^{9}$ Pruga Lupoglav-Štalije dugačka 52,7 kilometara naziva se i Raška pruga. Radovi na njoj započeli su u svibnju 1948., a dovršeni su u prosincu 1951. godine. Koristila se za prijevoz boksita, ali napose ugljena i bila je jedan od simbola povezivanja Istre s Hrvatskom (Istarska enciklopedija, 2005). 
Zanimljiva pripovijest sugovornice A. Š. koja je provela tri mjeseca na izgradnji pruge otkrila je detalje o politici provođenja takvih radnih akcija:

I onda hrana, hrana je bila kakova je bila, ali si ija. Ali u kruh su metali, tako da žene ki prvi dan ima menstruaciju prvi dan, drugi dan niš, a muški da im se ne diže. Alora pa bi bile žene došle s korijerom hodila za Riku, je hodila dva put na dan do Kršana, od Kršana do Pićna na noge si doša. Bi došle te žene donesti anke tu bjankerilu mužima, anke i ča za poisti. Jedan je reka: "Moja žena je pošla svadi s nami kja." A zašto? "Ja nis' moga i bok." A ona je parala da on ima tamo žene, da ima tamo žene. Ma je reka: "NE kad nam meću u kruh." Pa mi smo se smijali. Ja sam imala 17-18 lit. Taj prah su im stavljali u kruh, Trumanova jaja. To su nam prontivali Trumanova jaja, sve u prahu. To je bila žuta tekućina, prah i bi vrga vodu, to si stuka i si učinia fritaju. Ča si ija? Trumonova jaja bimo se bili zezali jedan s drugin. (A. Š., intervju) ${ }^{10}$

Značajno je da se udarnički rad, dakle onaj u kojem se pojedinci posebno zalažu tijekom obavljanja zadataka, u ranijem periodu rada tvornice mogao implementirati i izvan nje, odnosno zalaganje u tvornici bilo je komplementarno zalaganju i izvan nje. Drugim riječima, rad je bio prožet kroz privatnu i javnu sferu života, a tome svjedoče i radnice koje su gubile mjesečnicu što nije rijedak slučaj na radnim akcijama među kojima Lupoglav-Štalije nije bila izuzetak (usp. Matošević 2015b: 98-100). No, zalaganje kao i moguće dobivanje priznanja "počasnog zvanja" udarnika, za razliku od radnih akcija, u postrojenjima je bilo, prema riječima radnica prve generacije koje su se natjecale, praćeno i višom novčanom retribucijom:

Ali u sedam sati tih 10 minuti ti je pošlo u normu. Zato nisi ni u zahod poša, pa samo čim više da učiniš jer plaća je bila mižerna, i ko si učinia za to si bia udarnik. Jer na primjer ko si činia 50, 100 je bila žurnada, ali ako si ti prebacia [još] 50, e to ti je! To je ritko ki jer neki je jedva stiga, neki kako si se snaša, kako si bia spretan i tako. [...] Jer kad si ti bia udarnik, čak si ti tu i neku nagradu dobia, koliko je bilo se ne sjećam, ali si dobia nagradu. Novčanu nagradu! Da. Pa sve se gledalo kroz novac moja! E da. (A. Š., intervju)

Bilo je toga, da, bilo je toga, po svih tvornica je bilo. Tako da se natičeš, da što više učiniš. Jer onda je bilo u interešu čim više učiniti. (M. H., intervju)

\section{ASPEKTI UVJETA RADA I ZDRAVLJE}

Pulski je "biro rada" pedesetih i šezdesetih godina dvadesetog stoljeća sve žene usmjeravao u tvornicu, koja je zbog povećane proizvodnje i izvoza bila u potrazi za ženskom radnom snagom. Mogućnost dodatnog usavršavanja vodila je k promaknuću, pa i rukovodećoj poziciji, a tijekom zlatnog razdoblja šezdesetih godina u tvornici je bilo više od 1000 zaposlenih (Bonfiglioli 2017). Ženama s umanjenom radnom sposobnošću omogućavalo

\footnotetext{
${ }^{10}$ lako spominje "Trumanova jaja”, odnosno jaja u prahu, koja su bila sastavni dio poratnog paketa pomoći UNRRA-e, kao izvor gubitka mjesečnice, odnosno erekcije kod muškaraca, vrlo je vjerojatno da su im u hranu stavljali "brom, arsen ili crnu alvu i na taj način susprezali manifestaciju spolnog nagona" (Jambrešić Kirin 2008: 90).
} 
se kraće radno vrijeme, a svima je na raspolaganju bila menza s kuhanim obrocima (usp. Bonfiglioli 2017). ${ }^{11}$ Unatoč tim pogodnostima radnice su nosile dvostruki teret, zamaha industrijalizacije i kućanskog posla, zbog čega je tvornica i za njih bila izvorom "ambivalentne ljubavi", što je sintagma koju Andrea Muehlebach koristi pri naglašavanju modernizacijskih procesa u drugoj polovici dvadesetog stoljeća koji od tvornica kao "mjesta ozljeda i smrti [...] počinju činiti mjesta sigurnosti i osiguranja od rizika ozljeđivanja i starosti” (2017: 120). No, možda bi se značenje navedene sintagme također moglo proširiti na međuovisnost obiteljskih i obaveza na radnome mjestu:

Jer su žene bile manje nego makovo zrno. A danaska nisu. Ti kad si se oženia, ti si tendija svoju familiju, muža, dicu, kuha, pegla, pra, sve. Ne daj Bože da je muž, iako ste delali obadva, si spremala navečer, ali kad si doša doma ili si onda na brzinu nešto skuha ili dicu sve je to, onda si ima za prati i suđe, si ima za prati na ruke. Si pra, si pegla, si sređiva [...] . Tu i tamo se neki muž ferma u neki oštariju i tako, ali ti ne bi bila pošla na kafe za cili svit. Jer na obali je bia, mi smo je zvali Gradska kavana, kemu je vrga došlo na glavu da bi ti tamo poša na kafe. A danaska tega ni. Dica, forši, pet-šest dani si ih pratia u školu, pokle su pošli sami. Nije bilo kao danas. Je bilo sigurno, je bilo sve. I je bilo žena, bilo je muški, kad si dobia plaću si ju morala njemu dati. Je bilo i takovih. Dijelili. Svakako je bilo. Ali žene su držale do familije. A sad te familije ni. Ne daj Bože, ja ti opet govorim. Meni moj muž je stvarno bia pomoga, mi smo si jako pomogli. (A. Š., intervju)

Ovaj iskaz svjedoči o samodisciplini za koju se zasigurno može ustvrditi da je "predmoderno nasljeđe ženskih uloga i vrlina, kao što su spremnost na žrtvu i odgovornost za prosperitet obitelji i zajednice kao cjeline" (Jambrešić Kirin i Blagaić 2013: 42). Drugim riječima, iako su industrijsko oživljavanje Jugoslavije i uključivanje žena u proces rada imali značajnu ulogu u društvu te je u tom smjeru djelovao Antifašistički front žena Jugoslavije, za njih je to nerijetko značio double burden (Bonfiglioli 2008: 41; 2017), dvostruki rad. Arena trikotaža u tom smislu, također, nije bila izuzetak.

Mogućnost financijskog doprinosa u vlastitim kućanstvima i društvena klima ravnopravnosti spolova bile su snažna motivacija za svakodnevno hvatanje u koštac s, kako kažu naše sugovornice, "nepravdama" ili "konkretnim uvjetima rada". Sve do kraja 1990-ih u tvornici je bio i liječnik, kojemu su se radnice mogle obratiti za pomoć. lako su sve naše sugovornice o tome govorile samo s pohvalama, liječnička prisutnost u tvornici svakako otvara pitanje o profesionalnim bolestima uzrokovanim osmosatnim sjedećim radom. Godine 1995. na temelju istraživanja rada u "tekstilnoj industriji ustanovljeno je da 40,6\% radnica, opterećenih brzinom rada, pregrizaju konac zubima umjesto da upotrijebe škare,

${ }^{11}$ Po otvorenju tvornice rad je bio podijeljen $u$ tri smjene. Jutarnja smjena bila je od 6 do 14 ili 15 , popodnevna od 14 do 22 ili od 15 do 23, dok se noću radilo od 22 do 6 . Prema kazivanju I. A., popodnevni rad bio je plaćen $25 \%$, a noćna smjena čak $50 \%$ povrh osnovne plaće. Već 2000 -ih prešlo se na rad samo u jednoj, jutarnjoj smjeni. Žene s djetetom do tri godine bile su oslobođene rada u noćnoj smjeni, što više nije bio slučaj za radnice koje su čekale mirovinu početkom 2000-ih. Unatoč dobi od šezdeset godina sugovornica I. A. morala je raditi u noćnoj smjeni za vrijeme hitnih isporuka: "Zadnju godinu prije penzije sam radila po noći. Svaku drugu sedmicu, a često. Zadnju godinu prije penzije sam radila u kemijskoj i po noći. I onda drugu radiš ujutro" (I. A., intervju). 
kako bi konac brže uvukle u iglu šivaćeg stroja što je dovelo do stvaranja uzura na zubima" (Norčić i dr. 1995: 147-152). Također, govoreći o zdravstvenim tegobama, sugovornice su najčešće isticale gubljenje vida uslijed višesatnog koncentriranog gledanja u sitne rupice ketlerice ili ovrloka i bolesti kralježnice:

A žene su itekako izgubile oči. Izgubile vid. To je jako teško, su sitne tako, a stalno piljiti u to. I onda i kičma ti strada. I sve, ali dobro, nisu se žalile žene. Nisu se žalile. Svaka je volila svoju mašinu. Recimo, ona je volila svoju mašinu, ja sam svoju volila. Meni je bilo rađe raditi na mojoj nego da bi išla na njenu. (D. B., intervju) ${ }^{12}$

Zarada je nerijetko ovisila o brzini i spretnosti, a brzina i spretnost o iskustvu koje se gdjekad plaćalo upravo narušavanjem zdravlja:

A norma je bila katastrofa! Ono nikako nisam mogla uhvatiti tu normu. [...] niti ne znam da li sam pola napravila. Za to ti treba godinama da bi uopće ušao u to. To je ogromna mašina koja ima iglice, ona je sva u iglicama i sad ti moraš svaku rupicu i tu iglicu. I to moraš imat oči, ono, ko krofne velike. Za to ti treba brzina. One su to znale nabadat. A taj kotač se vrti i ti moraš imat brzinu. I ti moraš pogodit. I onda sam ih ja usporavala. Nikada to $u$ životu nisam radila i normalno dok bi ja napravila jednu, žena bi dvadeset majica. Ipak je to bilo dvadeset godina više rada. Ona je mogla i žmurečki to. (D. B., intervju)

Iz istraživanja proizlazi da su radnice bile spremne prijeći preko manjih nepravdi na koje su nailazile, sve dok je isplata plaća bila redovita, a dvaput godišnje, kako kažu, i "podebljana”:

I opet govorim, nije ni meni bilo vajk pravo. Kako si ti prihvatio situaciju i sredinu. Ti si mora gledati da je to tvoje. Mi smo bili sretni kad smo napredovali, kad smo puno prodali. Pa smo samo govorili: "Ćemo dobiti višak? Ćemo dobiti višak?” Znaš, više plaće. To je bilo dva puta na lito, za 29. novembra i za 8. mart. Ti, kad ti dobiješ dvi plaće svoje to te dobro rine. To, samo to smo čekali. (A. Š., intervju)

U svoje zlatno doba, 1960-ih, tvornica je proizvode izvozila u Rusiju, Njemačku i Ameriku. Sugovornice se sjećaju kamiona koji su iz tvorničkog kruga izlazili tri puta dnevno, pa i toga da su i žene iz Uprave, ako se za tim pokazala potreba, pomagale u pakiranju i drugim poslovima:

Radili smo i za Kineze. To je bilo najbogatije razdoblje, mislim. Jer njih je bilo puno, nije bilo zabrane rađanja. Mi smo tri godine radili isti artikal. Znaš kada jednu stvar stalno radiš. To ti ide. To si imao norme znaš kako. Za njih smo jako puno bili radili. I tko bi rekao da će sad oni zavladati svijetom. Ali jadni, da ti znaš koje stvari smo mi radili da ti je muka bila. Sada gledaj. Za Rusiju smo isto dosta radili. Ma znaš to. Naši proizvodi su bili jako kvalitetni i svugdje su išli i svi žale za njima. Zbilja s kim god govoriš pa svi su

${ }^{12} \mathrm{O}$ takvom odnosu prema strojevima, kakvog se danas u vrijeme deindustrijalizacije nerijetko sjećaju nekadašnji radnici i radnice, svjedoči i događaj iz siječnja 1947.: Mario Lussi, Antonio Salgari i Lino Mariani poginuli su, a devetorica su se radnika ozlijedila u pokušaju sprečavanja demontaže i odvlačenja strojeva električnog mlina Sanse u Puli “od strane civilne policije uz dozvolu savezničke vojne uprave” (Glas Istre, 3. siječnja 1947.). Andrea Muehlebach svoje je slično zapažanje zaključila tvrdnjom da "stroj nerijetko znači i nečiji kruh, ali je ljubav prema strojevima zasigurno i efekt činjenice da su oni posredovali guste socijalne odnose [...] te spajali ljude - radnike s radnicima i radnike s obiteljima" (2017: 120). 
kupovali od Trikotaže. Nekad nisi kao danas mijenjao. Nego si kupio pa da ti traje. To je vječnost bila. To je stvarno bila vječnost. (M. T., intervju)

Velik zamašnjak radnom elanu bila je zasigurno mogućnost kontrole zarade kroz količinu proizvedenih artikla tijekom radnoga vremena, a koji je, čini se, suživio s praksom prekovremenoga rada. Potonji pak, svjedoče, nije uvijek bio regularno prikazivan, već se plaćao pod stavkom prijevoza što je bilo izuzeto s platne liste i taj je dio rada bio, tvrde, "rad na crno". Upravo takvi kontradiktorni uvjeti rada koji su radnicama omogućavali zaradu, ali istovremeno, čini se, i generirali osjećaj "zakinutosti", ponovo dovode u prvi plan situaciju "ambivalentne ljubavi":

To se sve davalo na crno oko. To je sve počelo mučke. Uglavnom tu su nas dosta zakinuli s prekovremenim radom. Ja sam zasluživala dobivati veću ocjenu jer su nas kao nagrađivali, pa bi ja jako malu ocjenu dobila na moj rad. To je bio kao neki stimulans. Mene se jako puno okidalo taj stimulans. Radila sam jako puno. A jako malo plaćena za to. Bilo je žena koje su dobivale taj stimulans, a koje su, tako reći, ovako stajale. (A. O., intervju)

Razlika među radnicama i njihovom zasebnom "snalaženju" svakako je stavka koju valja podcrtati, no zasigurno niti jedna od njih - bez obzira na to u koliko se boljoj ili lošijoj poziciji nalazila - nije mogla izbjeći normiranje učinka na svojemu radnome mjestu. Stoga je odnos s predradnicama koje su u mnogočemu definirale radnu svakodnevnicu, tvrde sugovornice, počesto bio od presudne važnosti.

\section{NORMIRANJE I PREDRADNICE}

Radnički savjet Tvornice trikotaže Olga Ban je 1956. godine u sedam glava i kroz 26 članaka u Tarifnom pravilniku detaljno objasnio što je norma, kako se ona izračunava i razlikuje od jednog do drugog radnog mjesta. Radne su se norme određivale u skladu s tim istim tarifnim pravilnikom poduzeća, dokumentom koji obrazlaže stupnjevanje i ocjenjivanje težine rada po kategorijama (HR-DAPA-104, 1958). Pravilnik o normama sastavljao je stručni kolegij koji su činili tehnički rukovodilac poduzeća, šef računovodstva, normirac, direktor poduzeća i šefovi odjeljenja. Radni kolektiv imao je pravo u roku od petnaest dana od službene objave Pravilnika o normi na oglasnoj ploči poduzeća uložiti žalbu ili prigovor. U Pravilniku stoji da je tehnički rukovodilac dužan voditi brigu da postavljene norme budu realne. Određivanje normi postizalo se mjerenjem prosječnog radnog učinka među radnicima, a jednom donesene norme se više nisu smjele smanjivati već samo povećavati, što je pravilo i u ostaloj domaćoj, kao i svjetskoj privredi (Littler 1982: 84, 95, 112). Radne norme su bile izražene na dva načina: ili prema količini proizvoda za jedinicu vremena (količinske) ili prema količini vremena za jedinicu proizvoda (vremenske). Ukoliko se radnik nije slagao s visinom utvrđene norme, spor je rješavao Upravni odbor u roku od tri dana. Utvrđene norme rada nisu se mogle mijenjati kroz vrijeme od šest mjeseci, a svaka je norma bila na probnom roku od mjesec dana. Norma bi se iznimno mijenjala ako 
bi na jednom artiklu 50\% radnika prebacilo normu za 20\% ili ako je 50\% radnika postizalo $80 \%$ norme. Sugovornica I. A. se prisjeća:

Dobiješ ugovor, ali ti kažu, straše te, da ćeš dobiti otkaz ako ne napraviš normu. Ako ti više napraviš, dobiješ višu plaću. Ako manje napraviš, manje dobiješ. Ali oni ne vole, hoće normu da izvršiš. (I. A., intervju)

Radnice koje su bile pedantne i kojima se roba nije vraćala zbog, kako tvrde, "šlampavog šivanja" bile su pohvaljene, no to je ujedno značilo da je optimalna produktivnost pojedine radnice dovedena do maksimuma što jest bio cilj. S modernizacijom se započelo krajem 1960-ih i u pogon je uvedena radna traka. To je iziskivalo i manje promjene u načinu rada. Sada je svaka radnica imala svoje mjesto na traci i sve sugovornice su naglasile važnost dobrog odnosa s predradnicom čija je uloga u odnosu na radnice bila višestruka: distribuirala im je materijal za obradu, nadgledala ih je i kontrolirala:

Ako ste bila dobra s ovom predradnicom ste anke malo bolje dobili delo jer znate norme, smo imali normirka, i vajka je došla ta normirka, ajme koliko su je kleli, Majko Božja. (M. H., intervju)

Situacija odnosa s predradnicom koju je radnica opisala nije rijetkost. Slično se dešavalo u mnogim postrojenjima u kojima je direktnu kontrolu nad radom "imala nadređena osoba". Primjerice, Craig R. Littler piše o "omraženom predradniku" (1982: 86), odnosno figuri u postrojenjima koja je s vremenom gubila neograničenu moć koju je u početku imala, ${ }^{13}$ ali je uvijek djelovala kao posrednik između radionica i radnika i uprave (isto: 88). lako je predradnik figura koja je u industriju uvedena koncem devetnaestog stoljeća, odnos prema njima gotovo je uvijek bio protkan strahopoštovanjem. Na radnice su ponekad imale toliki utjecaj da su ove "preskakale" marendu kako bi povisile vlastiti učinak, što je pak moglo imati i pozitivan utjecaj na njihovu zaradu, ali i samopoštovanje kao radnika:

Čak se sjećam da su mi govorili nemoj in nikada ništa pitat, pogotovo za plaće. Nemoj ništa pitati. Koliko napraviš, toliko ćeš dobiti. [...] Svaku kunu si zaradio. Nije bilo fiksnog dijela. I to ono, čak smo znali mi novi, jadni, neke pute preskočiti marendu da bi napravio dve-tri majice više da im se približiš. Ili bi ostao popodne još par sati da natučeš koju maju, ono da se malo dokažeš da se trudiš, da si ono vrijedan, da možeš i ti. (D. B., intervju)

Događalo se, rekle su nam naše sugovornice, da su i kontrolorke kvalitete vraćale ispravnu robu što je znalo rezultirati svađom s radnicama. Normirke su, pored predradnica i kon-

\footnotetext{
${ }^{13}$ Predradnici su u industriju uvađani na prijelazu iz 19. u 20. stoljeće i nerijetko je do 1920. "cijeli industrijski život radnika bio u rukama njihovih predradnika. Predradnici su birali radnike na vratima postrojenja; često su direktno odlučivali o njihovoj plaći; avans ili povećanje plaće nisu bili mogući osim ako oni nisu tako odlučili; odlučivali su o cijeni rada i imali su moć sniziti je prema vlastitoj želji; i... gotovo uvijek je imao neograničenu moć davanja otkaza" (Atheanum prema Littler 1982: 86). Dakako, moć predradnica u Arena trikotaži nije bila niti približno tolika i u skladu je s povijesnim razvojem njihove uloge koja se ponajviše očituje u "nemogućnosti da zapošljava i otkazuje posao" (isto: 88), ali je naglašavala razliku među radnicama i ostalim osobljem, te su, prema sjećanjima radnica, predradnice bile izvor autoriteta prema kojima se odnosilo sa strahopoštovanjem jer je njihova moć bila u tome, kažu, da radnu svakodnevnicu učine lakšom ili težom.
} 
trolorki, pak bile "strah i trepet", karika čiji je utjecaj na iznos mjesečne plaće bio presudan. Ona je stajala pored radnica i vrednovala kvalitetu "svakog artikla". ${ }^{4}$ Predradnice su dobivale upute od šefova i prema tome su određivale tko će gdje i što raditi. Stoga je odnos s njima trebao biti "stabilan i prijateljski" jer su one bile te koje su posredno mogle utjecati na ukupnu mjesečnu zaradu.

Sukladno modernizaciji tvornice i procvatu ekonomije naglasak se početkom 1960-ih počeo stavljati na zadovoljstvo radnika, ne samo na radnom mjestu već i izvan njega - "Država je spoznala da samo jak i odmoran potrošač može biti dobar radnik i sretan građanin pa je do kraja 1960-ih kampanja za plaćeni godišnji odmor bila jaka" (Duda 2005: 73). U vrijeme kolektivnog ljetnog godišnjeg odmora u samoj se tvornici obavljao remont: čistila su se skladišta i popravljale mašine. Drugim riječima, tvornica se pripremala za sljedeći godišnji proizvodni ciklus. No, praksa kolektivnog godišnjeg odmora ukinuta je početkom 1990-ih godina pa se takvo ukidanje može interpretirati jednim od simptoma propadanja poslovanja, što je u konačnici rezultiralo propašću tvornice.

\section{POČETAK KRAJA FABRIKE}

Suvremena istraživanja politika rada u socijalističkoj Jugoslaviji ukazuju na to da se uspješnost radnika i radnih kolektiva mjerila ispunjenjem plana, a ne nužno kvalitetom proizvoda (Dobrivojević 2013: 28). Tvornica trikotaže Arena od svojih se početaka isticala kvalitetom proizvoda, zbog čega je dobila nekoliko državnih priznanja poput plakete "Kate Pejnović" (Stojšić 1982: 187). Također, zahvaljujući dizajnerici Mariji Vareško, tvornica je više puta bila nagrađena državnim priznanjima. Nažalost, rad visokih standarda nije opstao s promjenom društvenog uređenja sredinom 1990-ih. Iz naših razgovora o radu u tvornici Arena trikotaža proizlazi da je pad kvalitete proizvodnje rezultat promjena koje je donijela privatizacija. Značajnu promjenu u pogonu donijelo je također i ukidanje normirke 1995. godine:

A sad u zadnje vrijeme kad se više nije normiralo je na oko data norma, a u stvari to se diglo itekako. Na primjer, te naramenice su bile 120 komada kad sam ja počela raditi, završile su na 500! Na dan! U osam sati, draga! Je bilo moguće je, jer si radio kao magarac. Si bio razapet kao magarac na mašini. Srećom nisi radio non-stop to. [...] Nitko nije brojao normu. Prvo smo slale posao po traki dolje. Normalno, bile su male etiketice na njoj i onda bimo pisale koliko komada i artikal. I te etiketice smo imale posebne knjige u koje je predradnik lijepio posao. Znači svaki dan je taj posao bio u knjizi. Pa je došlo vrijeme da smo si same u tu knjigu morale pisat. Pa na kraju, to je izgledalo odvratno. Jer mi smo bile plaćene da radimo, a ne da radimo taj posao. Poslije toga se počelo isto pisat, ali samo na papir koji ste dobili i onda bi išao na pregled kod glavnih šefova koji su bili za to. Bilo je svega. Bilo je žena koje nisu nikada normu napravile, a napisale. Bilo je,

${ }^{14}$ Povijesno gledano, kontrolori i normirci u industrijskim postrojenjima proizlaze iz uloge predradnika, ali $u$ isto vrijeme znače i slabljenje njegove moći jer su njihove uloge prethodno bile u njegovoj domeni (Watson i Levine prema Littler 1982: 87). 
ali nažalost, kako se kaže netko na lijepe oči prođe, a netko mora raditi. Recimo kad sam radila prekovremeni rad nikada nam nisu prikazivali, a smo ga radile. (A. O., intervju)

U isto vrijeme došlo je do ukidanja radnog mjesta tvorničkog liječnika, nakon čega se uvela mogućnost izostajanja s posla bez prijave bolovanja, uz obećanje nadređenima da će se izostanak odraditi naknadno. Jedan od naših sugovornika nagađao je o razlozima tako "opuštenog" odnosa:

Znači od kada je nastala nova država sam osjetio da je ta država, ta disciplina nije bila kao što je nekada bila. Možda zato jer je jednostavno, ne znam, da li zato što je većina tih ljudi koji su ovdje radili na položaju rukovodioca i sami bili radnici, dosta ih je bilo. Bili su radnici, pa su išli u školu pa su možda osjetili da nije to trenutak, a drugo nije bila pravi vlasnik tvornice da bi mogao nametnuti svoju volju preko svojih ljudi. Nego je ipak to bilo, možda zato što jednostavno nije bilo pravog vlasnika i nije mogao tako napravit. Bitno je bilo da firma ide, sve nekako laganini. Polakše je išlo, nije se gledalo sitnice i tako, ako je netko imao obaveza skočiti kući ako mu je dijete ostalo kod zubara - nije bilo (više) ambulante. I tako uvijek si gledao kroz prste. (N. G., intervju) ${ }^{15}$

Mnogi tvrde da je devedesetih nadzor, a s njime i rad u pogonu popustio što je nužno imalo utjecaja na proizvodnju. Nekadašnji radnici ponekad su postali predradnici te popuštali iz kolegijalnosti i empatije. Stoga, osjećaj da je autoritet "šefova" također bilo izrazito načet, vrlo je prisutan:

A mogu reći da su onda još šefovi bili puno bolji nego sad u zadnje vrijeme. Jer su znali svoj posao. Znali su svoj posao. Recimo, mi smo imali tehnologa - šef koji je bio zadužen za proizvodnju cjelokupnu i njima je posao bio u malom prstu dok ove druge kad bi nešto pitao - "To ti ide tako; to ti ide tako", ali ti nitko ne bi znao sjesti na mašinu i pokazati kako ide. A ovi bi sjeli i pokazali, a ovi nisu, oni su više-manje - "Ja sam šef". Ma šta si ti šef? Šta si šef kad nemaš pojma o poslu? Mi smo vidjele jako puno tih grešaka. Zato jesu zadnje vrijeme bile jako puno grešaka. Recimo, ako je šef kako treba ako vidi da taj posao ne ide, taj posao treba vratiti. Treba napraviti kako treba da bi to išlo i dalje i da bi to bilo kvalitetno. Ali nažalost je i išlo tako kako je išlo. Je išlo krivim putem. (A. O., intervju)

Ideja o većoj sposobnosti, znanju i kompetentnosti radnika u odnosu na predradnike ili "šefove" u mnogim je postrojenjima česta pojava i bazirana je na percepciji razlikovanja radnika od ostalih, u prvom redu upraviteljskih ili tehničkih struktura. Takav osjećaj superiornosti proizlazi iz ideje da "pravo znanje" proizlazi iz prakse i manualnoga rada koji je,

${ }^{15}$ lako je jutarnja smjena uvijek počinjala u 8:05, nakon "popijene kave", promjenama devedesetih ukida se i to nepisano pravilo te smjena počinje točno u 8:00 sati. Riječju predradnika: "Teško je to, sad se odjednom preokrenuti i kazati ‘E čuj, nemoj sad tako, treba dolaziti u 8!', a cijeli je život i ona dolazila u 8:05. I kako sad njemu objasniti to. A trebaš ga evidentirati. Onda, znam da žena koja je radila zadnjih deset godina, znala je kao zapisati pa ne predati ili jednostavno se znala maknuti kad je znala da će netko zakasniti da ju ne vidi. I tako da smo, tako smo radili. Ja sam znao često mijenjati tu ženu iz kolegijalnih razloga jer ona je imala problema nešto kući, ovamo-onamo, i onda bi bio tamo sam joj rekao: 'Kad sam ja tu, nemoj mi molim te ovuda prolaziti. Imaš tamo ona velika vrata prođi onuda i nitko neće znati. Bitno da te ja ne vidim niti da, još bitnije, tebe ne vidi šef da si prošla pored mene. To je najbitnije'. I tako. Čuvali smo si leđa. Morali smo. Sad će njemu na plati uzeti 200 kn, i to će ga više demotivirati, više nego tih 200 kn, to što BAŠ NJEGA! Evo baš njega. Pa onda pet mjeseci nitko, a opet će svi kasniti” (M. G., intervju). 
povijesno gledano, "povezivan s idejom o socijalnoj superiornosti maskuliniteta, dok je misaoni rad povezivan s idejom o socijalnoj inferiornosti femininiteta" (usp. Willis 1977: 148). ${ }^{16}$ Dakako, femininitet i maskulinitet u ovom kontekstu ne mogu biti korišteni kao karakteristike spola, već osjećaja superiornosti temeljenog na "konkretnom”, "opipljivom” učinku vlastita rada koji proizlazi iz "manualnog iskustva” obavljenog posla za koji se prima plaća. I upravo je plaća, retribucija za vlastiti rad, bila izvor ponosa i osjećaja neovisnosti ili jednakog doprinosa u obitelji za mnoge radnice. No, plaće su stizale redovito do sredine 2013. godine i tada Arena modna trikotaža odlazi u stečaj, a priče o propadanju dionica tvornice ukazuju na ogromno nezadovoljstvo koje radnice i danas osjećaju:

Mi nismo imale veze za te dionice, ja nisam imala pojma o dionicama. Mi smo trebali izabrati žene koje će biti u tome. Jer sastanci su se održavali, imali smo, recimo, Radničko vijeće - u njemu su bile šefovi, od jednog pogona ili drugog, predradnice, a radnik je bio odabran koji je njima odgovarao. Ne radnici koji, dobro mi se nismo htjeli, ali da smo se mi među sobom, da je radnik bio - i da se njega posluša. Onda u ono vrijeme kad su došle dionice - to su nas dosta prevarili. Došle su negdje 1990-ih i plaćale smo mi, i mogu reći grdne pare smo dale. Za jednu dionicu, mislim - mjesečno sam odvajala za dionice $150 \mathrm{kn}$. A što sam dobila od njih - ništa. A da bi pokojni R. htio kupiti nudio je 100 kn po dionici. Plaćale smo za tih 24 dionice koliko je, ja sam njih plaćala 10 godina, to nije malo. Ništa od toga neću vidjeti, gotovo, popapala ih maca. Evo šta su napravili. A hoće da im budem zahvalna. (A. O., intervju)

Ona je rekla da moramo svi uzeti i da ćemo bolje stajati. Evo sad vidite kako su oni nas povukli. Evo, iskreno, sad kad je čovjek neuk, kad moram tako reći. Jer jedino što smo mi vidjele je posao, posao, posao. Daj plaću i ja sam na miru i drugo me ne pitaj. A taj put ona je rekla, ovako nas je povukla: "Kupite dionice i svako toliko ćete imati dividendu." Jedan put smo dobile dividendu. "Pa poslije će vam to ostat. Ćete moći pustiti svojoj djeci u nasljedstvo." I to me povuklo. To je sve glupo, ideš na riječ, ne ideš glavom. A kad ti direktor kaže uvijek misliš da ti govori za bolje. Ja nikad nisam mislila da će firma propasti. Nikad. Recimo kad su se te odluke, sve se odlučivalo, ali mi nismo bili uključeni u to. Uopće. (S. K., intervju)

Nekadašnju sigurnost pa "čak i opuštenost, a tada možeš dati sve od sebe" (D. B, intervju) nakon kratkog razdoblja entuzijazma zbog pretvaranja tvornice $u$ dioničko društvo zamijenio je osjećaj strepnje i nesigurnosti. Nakon dvotjednog štrajka zbog neisplate plaća radnice Arene su za Dan žena 2014. godine organizirale "posebnu modnu reviju i kulturni program održan ispred postrojenja trikotaže gdje su se nosili odjevni predmeti nastali upravo u ovoj modnoj kući”. Na reviji je uz glazbeni program i čitanje pisama podrške dizajnerice Marije Vareško, radnica Kamenskog te Domaće tvornice rublja Zagreb, "[n] astupilo 40-ak manekenki i manekena, od kojih su polovica bili upravo djelatnice i dje-

${ }^{16}$ Dobar primjer takvog odnosa prema "tehničkoj inteligenciji", inženjerima, dao je nekadašnji rudar raških ugljenokopa C. B. koji je, kako tvrdi, "zbog velike prakse koju je stekao kopajući ugljen, znao više i od samog visokoobrazovanog kadra: Tu bi se knjige pisale i tu smo mi postali geniji, moja generacija je postala genij. [...] jer inženjeri koji su pre nas bili nisu toliko znali, ni tehničari. Ali i njih je trebalo Ministarstvo [...] kada sam ja dela su bili i inženjeri unutra - ali nula! Ca mu rabi da je fini fakultet ako ne radi, ako nema praksu. On zna lajat teoriju, ali treba znati kamo ide i A i B i C" (Matošević 2011: 200). 
latnici Arene. Revija je bila lijepa, prošarana intenzivnim emocijama koje su se vidjele na licima arenašica. Neke su se nasmijale, ali neke su se mučile da suspregnu suze, dok se na većini njih vidjelo koliko teško proživljavaju stanje neizvjesnosti i obespravljenosti" (Glas Istre, 9. ožujka 2014.). lako je lokalna zajednica okupljanjem i donacijama tom događaju dala podršku, štrajk u svibnju 2014. godine završava, a otvara se stečajni postupak što označava definitivan kraj proizvodnje u Arena modnoj kući, trikotaži koja je bila snažnim znakom odlučnog uključivanja žena u industrijski modernitet grada Pule.

\section{ZAKLJUČAK}

Sigurnost i opuštenost o kojima je naša sugovornica progovorila, a koje mogu rezultirati zalaganjem, elanom i zadovoljstvom, u doživljaj se radne svakodnevnice radnica i radnika u Arena trikotaži upisuju dvostruko. S jedne strane stoji poslovanje tvornice koje je od samih svojih početaka premreženo poteškoćama i bremenitostima poput zastarjelosti strojeva i nedostatka stručnog kadra koncem 1950-ih godina, ali ono supostoji s, u pravilu, rješavanjem tih istih teškoća kao i neupitnim zadovoljenjem egzistencijalnih potreba zaposlenih. Ta je sigurnost pak rezultirala nezanemarivim ponosom vlastitom proizvodnjom, ponosom na pripadnost radnoj zajednici kao i na zaradu i mogućnost doprinosa u ili pak izdržavanje vlastitih obitelji (usp. Tamboukou 2016: 58). S druge strane, cijeli niz svakodnevnih "otegotnih" okolnosti u radnome procesu - poput strepnje pred normirkama, predradnicama ili kontrolorkama kvalitete, kao i "nagradni” odlasci na pojedine radne akcije kojih su se prisjećale radnice zaposlene u poratnoj Tvornici Olga Ban, govore u prilog uključenosti pojedinaca i radne zajednice $u$ industrijske modernizacijske tokove sa snažnim rodnim i socijalističkim predznakom. Tih se poteškoća danas radnice prisjećaju kao nužnih, ali i savladivih prepreka. Stoga tvrdnju da "[b]rza obnova i industrijalizacija nisu bile moguće bez kulture natjecanja u ranom socijalizmu" (Jambrešić Kirin i Blagaić 2013: 42) treba shvatiti kao sastavni dio poratnog etosa u kojem su privatna i javna sfera života bile neodvojive, odnosno snažno isprepletene, a u čijoj su isprepletenosti sudjelovale i najbolje radnice, udarnice pulske trikotaže i time ujedno doprinijele obnovi i izgradnji i izvan vlastitog neposrednog mjesta rada na radnim akcijama. No, ako je Arena trikotaža išla ukorak s trendovima industrijskog moderniteta te činila njegov sastavni dio, onda se na njezin stečaj i nestanak zasigurno mora djelomično gledati i kao na lokalan odjek širih trendova gašenja postrojenja teške i lake industrije u Hrvatskoj i regiji uz simultanu privatizaciju te rezultat nestajanja "[p]osla kao takvog, dobro definiranog, stabilnog, sigurnog, zaštićenog i korektno plaćenog posla, socijalne konstrukcije kakva je u razvijenim zemljama u proteklih pola stoljeća bivala normom" (Matković 2004: 243). Posljedice takvog nestajanja već su upisane u tkivo grada gdje se na mjestu i oko nekadašnje trikotaže otvaraju Kuća istarskog maslinovog ulja kao i nekoliko pubova i kafića, što su djelatnosti koje su dijelom uslužnog, tercijarnog sektora, a koji je u gradu Puli i lstri potican i vezan uz sezonski turizam čime se mjesta nekadašnje proizvodnje pretvaraju isključivo u mjesta potrošnje. Sezonska privreda sa sobom donosi neke nove radne napore, "fleksibilno" radno vrijeme i 
socijalizacijske obrasce, uzrokuje neke nove migracije, potiče i diktira nove ili pak isključive sustave vrijednosti, no jednako važno, turizam uzrokuje i drugačiju identifikaciju građana s gradom. Sadržaj tih novih simboličkih i realnih veza analizirat će neka buduća istraživanja, možda baš u komparativnom ključu sa specifičnostima industrijske modernosti kakve je reflektirala i Arena trikotaža u Puli.

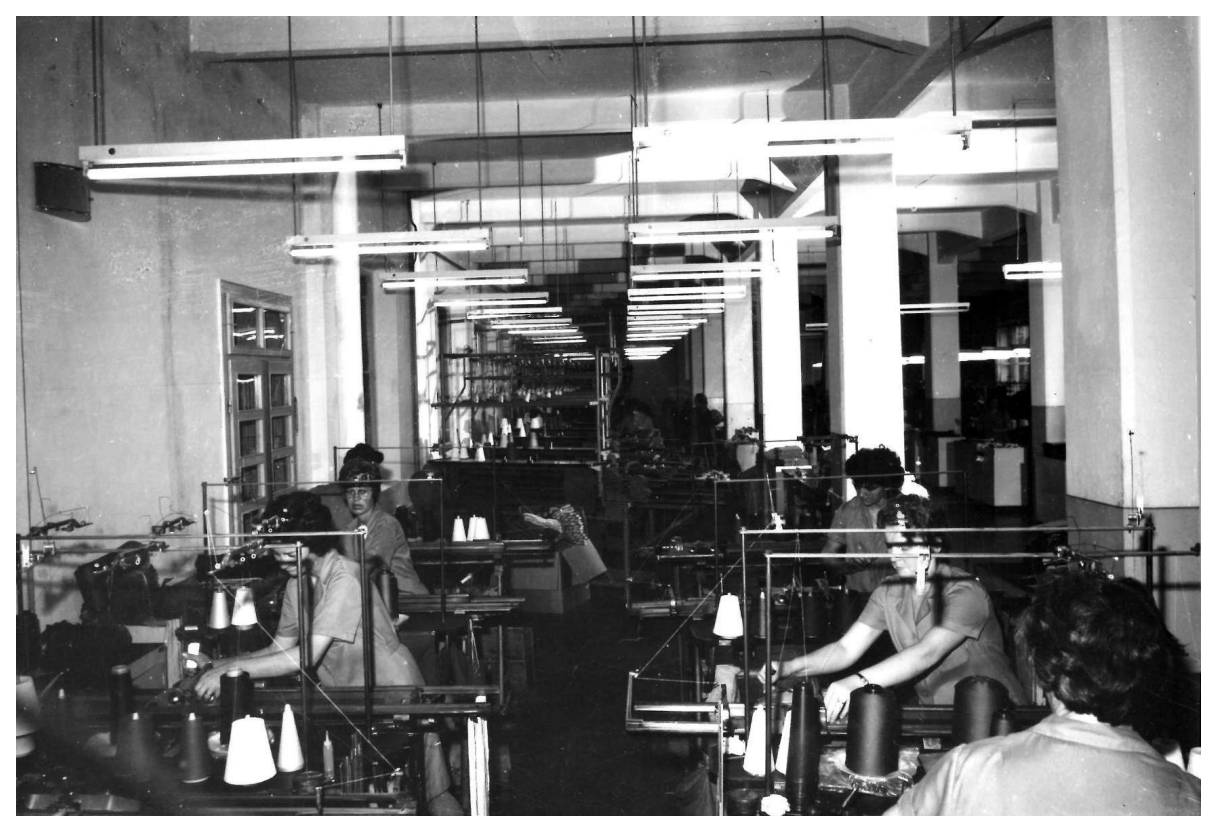

Rad u postrojenju Arena trikotaže

\section{NAVEDENA LITERATURA I IZVORI}

Bonfiglioli, Chiara. 2008. Belgrade, 1978. Remembering the Conference "Drugarica Žena. Žensko pitanje - Novi Pristup?"/ "Comrade Women. The Women's Question: A New Approach?” Thirty Years After. Utrecht: University Faculty of Arts, Women's Studies. Research Master "Gender and Ethnicity".

Bonfiglioli, Chiara. 2017. "Post-socialist Deindustrialisation and Its Gendered Structure of Feeling. The Devaluation of Women's Work in the Croatian Garment Industry”. Femnist Review 116 [rukopis u objavi].

Cvek, Sven, Snježana Ivčić i Jasna Račić. 2015. “Jugoslavensko radništvo u tranziciji. ‘Borovo' 1989”. Politička misao 52/2: 7-34.

Dobrivojević, Ivana. 2013. “Industrijalizacija kao imperativ. Ekonomska politika Partije 1945-1955”. U Socijalizam na klupi. Jugoslavensko društvo očima nove postjugoslavenske humanistike. Lada Duraković i Andrea Matošević, ur. Pula, Zagreb: Sveučilište Jurja Dobrile, Srednja Europa, Sa(n)jam knjige u Istri, 19-42.

Duda, Igor. 2005. U potrazi za blagostanjem. O povijesti dokolice i potrošačkog društva u Hrvatskoj 1950-ih i 1960-ih. Zagreb: Srednja Europa. 
"Fatima Zahirović, jedina zavarivačica u Uljaniku”. Glas Istre, 13. travnja 2013.

HR-DAPA-104, Narodni odbor općine Pula, Tvornica trikotaže Olga Ban, Pula, 1958. kut. 935.

Istarska enciklopedija. 2005. Zagreb: Leksikografski zavod Miroslav Krleža

Jambrešić Kirin, Renata. 2008. Dom i svijet. O ženskoj kulturi pamćenja. Zagreb: Centar za ženske studije.

Jambrešić Kirin, Renata i Marina Blagaić. 2013. "The Ambivalence of Socialist Working Women's Heritage. A Case Study of the Jugoplastika Factory". Narodna umjetnost 50/1: 40-73. [https://doi. org/10.15176/VOL5ONO102]

Littler, Craig. R. 1982. The Development of the Labour in Process in Capitalist Societies. London: Heinemann Educational Books.

Markulinčić, Hrvoje. 2005. “Uljanik Brodogradilište d.d.” U Istarska enciklopedija. Miroslav Bertoša i Robert Matijašić, ur. Zagreb: Leksikografski zavod Miroslav Krleža, 835-836.

Matković, Teo. 2004. "Nestajanje rada? Opseg i oblici zaposlenosti na početku informacijskoga doba". Društvena istraživanja 13/1-2: 241-265.

Matošević, Andrea. 2011. Pod zemljom. Antropologija rudarenja na Labinštini u XX. stoljeću. Zagreb, Pula: Institut za etnologiju i folkloristiku, Sveučilište Jurja Dobrile u Puli.

Matošević, Andrea. 2015a. Socijalizam s udarničkim licem. Etnografija radnog pregalaštva. Zagreb: Institut za etnologiju i folkloristiku.

Matošević, Andrea. 2015b. "Omladinske radne akcije. Kontinuiteti i odmaci iz iskustva akcijaša". Traditiones 44/3: 93-111.

"Modna revija radnika u štrajku. Arenini modeli vječni". Glas Istre, 9. ožujka 2014.

Muehlebach Andrea. 2017. "The Body of Solidarity. Heritage, Memory, and Materiality in Post-industrial Italy". Comparative Studies in Society and History 59/1: 96-126. [https://doi.org/10.1017/ S0010417516000542]

Nikolić-Đerić, Tamara. 2011. “Tabacheine' - žene u duhanskoj industriji”. U Kulturna dedeščina industrijskih panog/Industrijska kulturna baština. Alenka Černelič Krošelj, Željka Jelavić i Helena Rožman, ur. Ljubljana: Slovensko etnološko društvo, 274-286.

Norčić, Silva i dr. 1995. "Profesionalne uzure zuba u radnika tekstilne industrije". Acta Stomatologica Croatica 29/3: 147-153.

"Oni rade za drugu petoljetku". Glas Istre, lipanj 1949.

Pavlinušić, Jelena i dr., ur. 2017. Što je nama Dalmatinka dala? Tvornica i predionica konca Dalmatinka Sinj. Sinj: Kulturno umjetničko središte.

Senjković, Reana. 2016. Svaki dan pobjeda. Kultura omladinskih radnih akcija. Zagreb: Institut za etnologiju i folkloristiku, Srednja Europa.

Stojšić Ljiljana. 1982. "Trideset godina rada "Arene" modne trikotaže Pula". U Almanah Jugoslavenskog mediteranskog podneblja. Ivica Žderić, ur. Rijeka: Liburnija, 183-189.

Škokić, Tea i Sanja Potkonjak. 2016. “'Working Class Gone to Heaven'. From Working Class to Middle Class and Back". Narodna umjetnost 53/1: 117-132.

Tamboukou, Maria. 2016. Gendering the Memory of Work. Women Workers' Narratives. New York: Routledge.

"Uz dozvolu Savezničke vojne uprave izvlače se svi strojevi iz tvornica Pule. Civilna policija puca u radnike koji brane svoje strojeve". Glas Istre, 5. siječnja 1947.

Vodopivec, Nina. 2011. "Industrijska dedeščina in tekstilne delavke". U Kulturna dedeščina industrijskih panog/Industrijska kulturna baština. Alenka Černelič Krošelj, Željka Jelavić i Helena Rožman, ur. Ljubljana: Slovensko etnološko društvo, 228-242. 
Willis, Paul. 1977. Learning to Labour. How Working Class Kids get Working Class Jobs. New York: Columbia University Press.

\section{INTERVJUI}

I. A. (2014): rođena 1951., kontrolroka robe, peglanje, rad na ketlerici i krojenju. Etnografski intervju. Audio zapis u posjedu autora.

A. Š. (2014): rođena 1932., konfekcionarka na šivačem stroju. Etnografski intervju. Audio zapis u posjedu autora.

M. H. (2014.): rođena 1933., radnica na mašini u pletioni, ručni rad i rad u konfekciji. Etnografski intervju. Audio zapis u posjedu autora.

M. G. (2014.): rođen 1950., radnik u skladištu i voditelj skladišta. Etnografski intervju. Audio zapis u posjedu autora.

M. T. (2015.): rođena 1949., pletačica i repasir. Etnografski intervju. Audio zapis u posjedu autora.

D. B. (2015.): rođena 1972., radnica na hefterici i ketlerici. Etnografski intervju. Audio zapis u posjedu autora.

A. O. (2015.): rođena 1964., radnica na ovrluku i endlekici. Etnografski intervju. Audio zapis u posjedu autora.

S. K. (2015.): rođena 1969., radnica na ovrluku i endlekici. Etnografski intervju. Audio zapis u posjedu autora.

"WHEN YOU ARE FEELING RELAXED, YOU CAN BE AT YOUR BEST": ETHNOGRAPHY OF WORK IN PULA'S ARENA KNITTING FACTORY

The aim of this article is to provide an insight into a part of a rich and under-researched working history of garment industry in the Olga Ban or Arena modna trikotaža factory in the town of Pula that was founded in 1947 and declared bankruptcy in 2014. Eight interviews with former workers, whose testimonies are the primary source for the content of the paper, are used to highlight those memories that were claimed most important by the former employees; i.e. wages, conditions of work, women's "double burden", relations between workers and foremen, memories of labour actions as well as a memory of "decaying" conditions of work and relations within the "garment community" that coincides with the period of post-socialism. While the socialist period of work is described as difficult for women but better organized and existentially more secure, the factory management in the period of post-socialism is claimed to be too loose and more chaotic when compared to the previous one. From the worker's point of view, shutting down the Arena factory also meant dismantling a part of the local community within which women could gain financial emancipation and wider recognition.

Keywords: Arena trikotaža, Pula, industry, labour relations, conditions of work 